\title{
OPERATION MARKET GARDEN: CASE STUDY FOR ANALYZING SENIOR LEADER RESPONSIBILITIES
}

\author{
BY \\ LIEUTENANT COLONEL ELIZABETH ANN COBLE \\ United States Army Reserve
}
DISTRIBUTION STATEMENT A: Approved for Public Release. Distribution is Unlimited.

\section{USAWC CLASS OF 2009}

This SRP is submitted in partial fulfillment of the requirements of the Master of Strategic Studies Degree. The views expressed in this student academic research paper are those of the author and do not reflect the official policy or position of the Department of the Army, Department of Defense, or the U.S. Government.

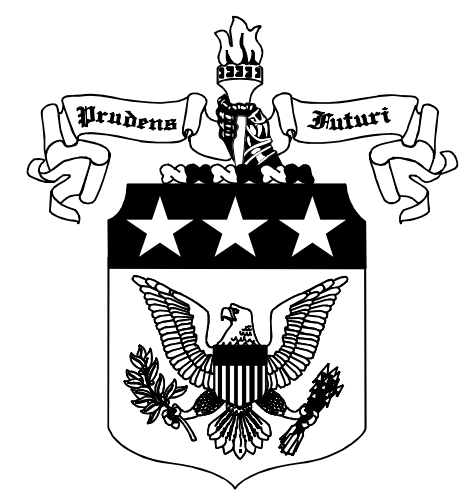

U.S. Army War College, Carlisle Barracks, PA 17013-5050 
The U.S. Army War College is accredited by the Commission on Higher Education of the Middle State Association of Colleges and Schools, 3624 Market Street, Philadelphia, PA 19104, (215) 662-5606. The Commission on Higher Education is an institutional accrediting agency recognized by the U.S. Secretary of Education and the Council for Higher Education Accreditation. 


\begin{tabular}{|c|c|c|}
\hline \multicolumn{2}{|c|}{ REPORT DOCUMENTATION PAGE } & $\begin{array}{c}\text { Form Approved } \\
\text { OMB No. 0704-0188 }\end{array}$ \\
\hline \multicolumn{3}{|c|}{ 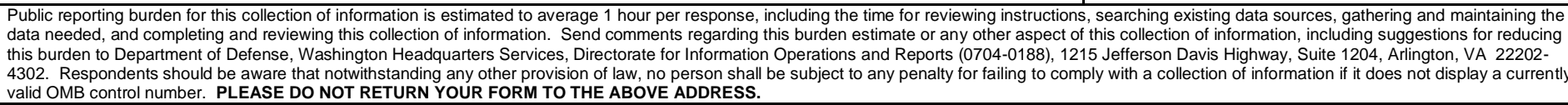 } \\
\hline $\begin{array}{l}\text { 1. REPORT DATE (DD-MM-YYYY) } \\
04-05-2009\end{array}$ & $\begin{array}{l}\text { 2. REPORT TYPE } \\
\text { Strategy Research Project }\end{array}$ & 3. DATES COVERED (From - To) \\
\hline \multirow{3}{*}{\multicolumn{2}{|c|}{$\begin{array}{l}\text { 4. TITLE AND SUBTITLE } \\
\text { Operation MARKET GARDEN: Case Study for Analyzing Senior Leader } \\
\text { Responsibilities }\end{array}$}} & 5a. CONTRACT NUMBER \\
\hline & & 5b. GRANT NUMBER \\
\hline & & 5c. PROGRAM ELEMENT NUMBER \\
\hline \multirow{3}{*}{\multicolumn{2}{|c|}{$\begin{array}{l}\text { 6. AUTHOR(S) } \\
\text { Lieutenant Colonel Elizabeth A. Coble }\end{array}$}} & 5d. PROJECT NUMBER \\
\hline & & 5e. TASK NUMBER \\
\hline & & 5f. WORK UNIT NUMBER \\
\hline \multicolumn{2}{|c|}{$\begin{array}{l}\text { 7. PERFORMING ORGANIZATION NAME(S) AND ADDRESS(ES) } \\
\text { Profess or Leonard Fullenkamp } \\
\text { Department of National Security and Strategy }\end{array}$} & $\begin{array}{l}\text { 8. PERFORMING ORGANIZATION REPORT } \\
\text { NUMBER }\end{array}$ \\
\hline \multirow{2}{*}{\multicolumn{2}{|c|}{$\begin{array}{l}\text { 9. SPONSORING / MONITORING AGENCY NAME(S) AND ADDRESS(ES) } \\
\text { U.S. Army War College } \\
\text { 122 Forbes Avenue } \\
\text { Carlisle, PA } 17013\end{array}$}} & 10. SPONSOR/MONITOR'S ACRONYM(S) \\
\hline & & $\begin{array}{l}\text { 11. SPONSOR/MONITOR'S REPORT } \\
\text { NUMBER(S) }\end{array}$ \\
\hline
\end{tabular}

\section{SUPPLEMENTARY NOTES}

\section{ABSTRACT}

With German forces on the run following the Allied success at Normandy and the breakout and pursuit across France, Allied forces were staged to enter Germany in late summer 1944. Both Field Marshal Montgomery and General Bradley clamored to be given the priority of effort. General Eisenhower chose Montgomery's Operation MARKET GARDEN as the plan for action. It called for airborne forces to open the route for a ground force to move more than sixty miles up a single road, ending up north of the Rhine River near Arnhem, Netherlands. By accomplishing this task, the German Ruhr industrial heartland would be within easy grasp. But the operation failed. The ground force did not make it to the last bridge; it was six more months before Allied forces crossed the Lower Rhine River near Arnhem. Between 17 and 26 September 1944, there were 17,000 Allied casualties including eighty percent of the 1st Airborne Division (UK). Did senior Allied leaders do enough to resolve issues raised before the operation began? Should it even have been conducted at all? This paper uses primary sources, including diaries, memoirs, and autobiographies, and unit reports, to examine what role senior leaders played in the failure of the operation.

15. SUBJECT TERMS

World War II, Airborne, Leadership

\begin{tabular}{|l|l|l|l|c|l|}
\hline \multicolumn{2}{|l|}{ 16. SECURITY CLASSIFICATION OF: } & $\begin{array}{l}\text { 17. LIMITATION } \\
\text { OF ABSTRACT }\end{array}$ & $\begin{array}{l}\text { 18. NUMBER } \\
\text { OF PAGES }\end{array}$ & 19a. NAME OF RESPONSIBLE PERSON \\
\cline { 1 - 2 } $\begin{array}{l}\text { a. REPORT } \\
\text { UNCLASSIFED }\end{array}$ & $\begin{array}{l}\text { b. ABSTRACT } \\
\text { UNCLASSIFED }\end{array}$ & $\begin{array}{l}\text { c. THIS PAGE } \\
\text { UNCLASSIFED }\end{array}$ & UNLIMITED & 42 & $\begin{array}{l}\text { 19b. TELEPHONE NUMBER } \text { (include area } \\
\text { code) }\end{array}$ \\
\hline
\end{tabular}



USAWC STRATEGY RESEARCH PROJECT

\title{
OPERATION MARKET GARDEN: CASE STUDY FOR ANALYZING SENIOR LEADER RESPONSIBILITES
}

\author{
by \\ Lieutenant Colonel Elizabeth Ann Coble \\ United States Army Reserve \\ Professor Leonard Fullenkamp \\ Project Adviser
}

This SRP is submitted in partial fulfillment of the requirements of the Master of Strategic Studies Degree. The U.S. Army War College is accredited by the Commission on Higher Education of the Middle States Association of Colleges and Schools, 3624 Market Street, Philadelphia, PA 19104, (215) 662-5606. The Commission on Higher Education is an institutional accrediting agency recognized by the U.S. Secretary of Education and the Council for Higher Education Accreditation.

The views expressed in this student academic research paper are those of the author and do not reflect the official policy or position of the Department of the Army, Department of Defense, or the U.S. Government. 



\section{ABSTRACT}

AUTHOR: $\quad$ Lieutenant Colonel Elizabeth A. Coble

TITLE: $\quad$ Operation MARKET GARDEN: Case Study for Analyzing Senior Leader Responsibilities

FORMAT: $\quad$ Strategy Research Project

DATE: $\quad 4$ May 2009 WORD COUNT: 8,450 PAGES: 42

KEY TERMS: $\quad$ World War II, Airborne, Leadership

CLASSIFICATION: Unclassified

With German forces on the run following the Allied success at Normandy and the breakout and pursuit across France, Allied forces were staged to enter Germany in late summer 1944. Both Field Marshal Montgomery and General Bradley clamored to be given the priority of effort. General Eisenhower chose Montgomery's Operation MARKET GARDEN as the plan for action. It called for airborne forces to open the route for a ground force to move more than sixty miles up a single road, ending up north of the Rhine River near Arnhem, Netherlands. By accomplishing this task, the German Ruhr industrial heartland would be within easy grasp. But the operation failed. The ground force did not make it to the last bridge; it was six more months before Allied forces crossed the Lower Rhine River near Arnhem. Between 17 and 26 September 1944, there were 17,000 Allied casualties including eighty percent of the $1^{\text {st }}$ Airborne Division (UK). Did senior Allied leaders do enough to resolve issues raised before the operation began? Should it even have been conducted at all? This paper uses primary sources, including diaries, memoirs, and autobiographies, and unit reports, to examine what role senior leaders played in the failure of the operation. 

OPERATION MARKET GARDEN: CASE STUDY FOR ANALYZING SENIOR LEADER RESPONSIBILITES

The higher up the chain of command, the greater is the need for boldness to be supported by a reflective mind, so that boldness does not degenerate into purposeless bursts of blind passion. Command becomes progressively less a matter of personal sacrifice and increasingly concerned for the safety of others and for the common purpose.

-Carl von Clausewitz, On War

Operation MARKET GARDEN was a strategic plan proposed by British Field

Marshal Bernard L. Montgomery and approved by Supreme Allied Commander General (GEN) Dwight D. Eisenhower. Considered a gamble, especially coming from the cautious Montgomery, its level of risk and probability of success were questioned by leaders and staffs of all effected echelons before it was conducted. And in the end, it was an overall failure. Between 17 and 26 September 1944, there were over 11,000 casualties among three participating Allied airborne divisions. This casualty count represented just under one third of the committed airborne force; it was more than among all Allies on 6 June 1944, the first day of Operation OVERLORD. ${ }^{1}$ There were over 17,000 Allied casualties, when the ground force numbers are included. More than one Allied division was lost in the 10 days of Operation MARKET GARDEN.

This paper will examine responsibilities in senior leader decision making, using Operation MARKET GARDEN as the case study. While understanding hindsight is $20 / 20$, it will consider what senior leaders said and did about the operation before it launched to determine if those responsible did what they were charged to do. It will also consider whether the plan was sound, or if it should have been conducted at all. 


\section{Overview of Situation - Western Europe - Early September $1944^{2}$}

After significant Allied ground gains following the breakout from Normandy until early September 1944, both Montgomery's $21^{\text {st }}$ Army Group (United Kingdom (UK)) and Lieutenant General (LTG) Omar N. Bradley's $12^{\text {th }}$ Army Group (US) were grinding to a halt due to a lack of supplies. The $21^{\text {st }}$ Army Group was generally along the BelgianDutch border, with fighting continuing in pockets along the coast, mainly around major port cities. The $12^{\text {th }}$ Army Group had crossed the Moselle River and was closing in on the German border south of the Ardennes Forest. LTG Jacob L. Devers' $6^{\text {th }}$ Army Group (US) was moving northeast through France following its success in southern France in Operation DRAGOON.

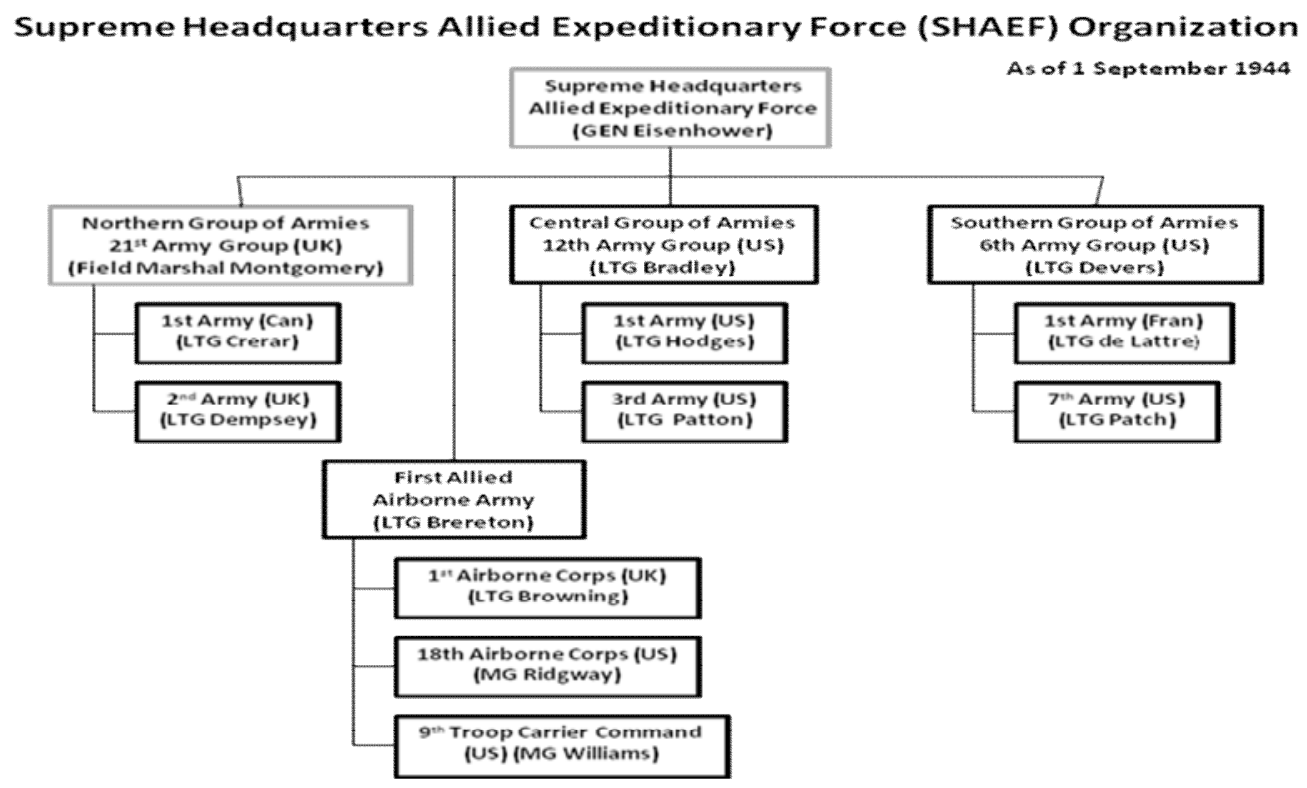

Figure 1.

Both Montgomery and Bradley were clamoring for supplies, most significantly gasoline, needed to continue their operations. Allied forces were still reliant on supplies being trucked predominately from the Cherbourg port in France, more than 400 miles from the $12^{\text {th }}$ Army Group. Allied bombing campaigns prior to OVERLORD destroyed 
the railway system in Western Europe which could have eased the strain. The US "Red Ball Express" trucked supplies to the front, but this was laborious. It took ten trucks to get five truckloads forward; vehicles wore out quickly. As for flying in supplies, the lack of aircraft, lift restrictions, and airfield availability limited this option. Attempts at opening new ports had yet to come to fruition. Although $21^{\text {st }}$ Army Group forces captured the major Belgian port city of Antwerp on 4 September 1944, they did not pursue the fight further so German forces still controlled the Scheldt Estuary and the fifty-mile water approaches to the port, making it unusable. Eisenhower had to determine how to prioritize the limited supplies which could be brought to the front.

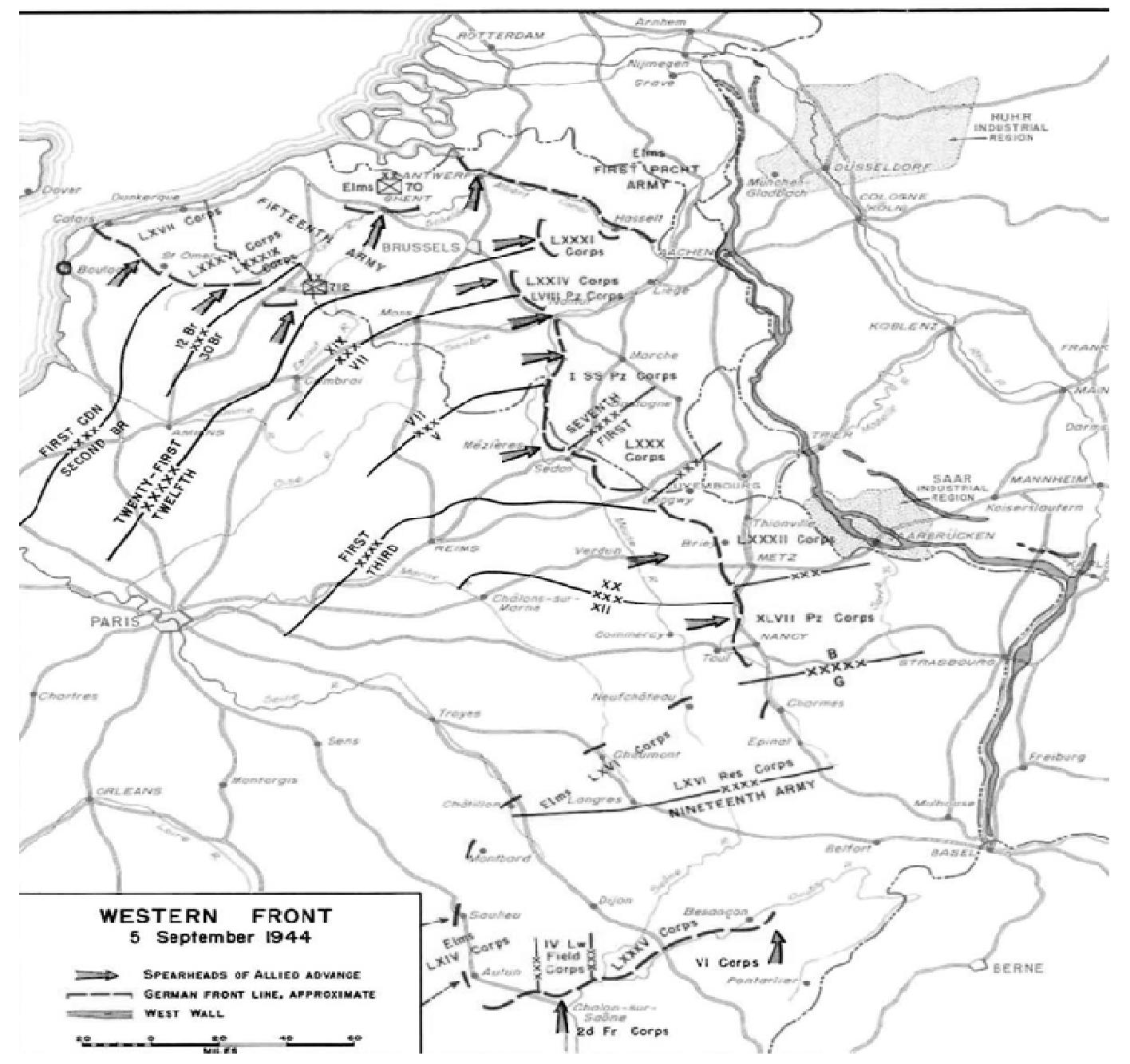

Figure 2. Situation on the Western Front -5 September $1944^{3}$ 
In addition to the supply concerns, Eisenhower juggled growing infighting and political considerations. Both Montgomery and Bradley thought their Army Groups were best aligned to enter Germany proper and quickly end the war. During Operation OVERLORD planning, Eisenhower, supported by US President Franklin D. Roosevelt and UK Prime Minister Wilson Churchill, decided on a "broad front" strategy for moving across Western Europe into Germany - Allied Armies would advance abreast. But by late August 1944, Montgomery - now with Churchill's backing - pushed for a change toward a "single thrust" strategy. The new idea was for one augmented Army Group to drive into German and on to Berlin with the other Army Groups defending with localized advances. At this stage, either way Eisenhower decided would cause additional strain on the political alliance and among his senior leaders - especially Montgomery and LTG George S. Patton, commander of the $3^{\text {rd }}$ Army (US).

Meanwhile, units of the newly formed First Allied Airborne Army (FAAA) were in England, waiting to get back into the fight. Used to build the Supreme Headquarters Allied Expeditionary Force (SHAEF) strategic reserve, the FAAA merged airplanes and crews with airborne forces under one commander, Lieutenant General (LTG) Lewis Brereton, to ensure airplanes were available to support airborne operations. Brereton, a US Army Air Force pilot with no practical experience employing airborne forces, would prove an unfortunate choice for this important command.

With the exception of a task force used to support Operation DRAGOON, airborne forces had not fought since being pulled out of Normandy in July 1944. The $82^{\text {nd }}$ Airborne (ABN) Division (DIV) (US) suffered more than 5,200 casualties, while the $101^{\text {st }}$ ABN DIV (US) had more than 4,600 casualties in Normandy. Both Divisions also 
lost many key leaders. They needed time to reconstitute, refit, and train new unit leaders before they were ready to reengage. ${ }^{4}$

\section{First Allied Airborne Army (FAAA) Organization}

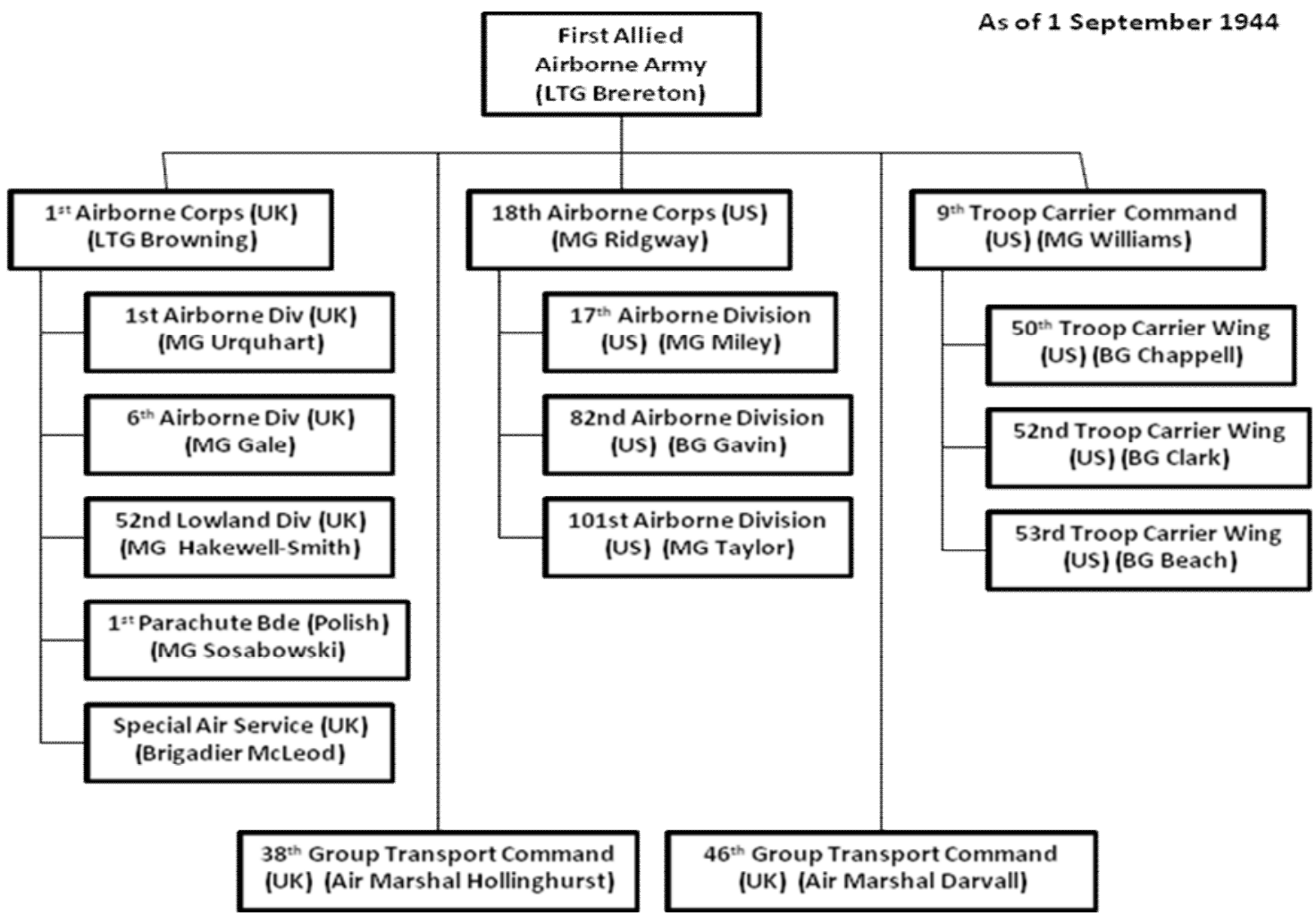

Figure 3.

Numerous airborne operations were planned but not conducted between

OVERLORD and early September 1944. Most were cancelled for one of two reasons:

the objectives were overrun by the speed of the Allied advance or bad weather. Leaders were restless.

\begin{tabular}{|l|l|l|l|l|}
\hline Codename & $\begin{array}{l}\text { Planned } \\
\text { Date }\end{array}$ & Drop Zone & Airborne Unit & Mission \\
\hline WILDOATS & $\begin{array}{l}14 \text { June } \\
1944\end{array}$ & Evrecy & $\begin{array}{l}\text { 1st ABN DIV } \\
\text { (UK) }\end{array}$ & $\begin{array}{l}\text { Clear way for 7th Armd Div } \\
\text { attack }\end{array}$ \\
\hline HANDS UP & $\begin{array}{l}\text { mid-July } \\
1944\end{array}$ & Quiberon & Undetermined & Seize ports \\
\hline
\end{tabular}




\begin{tabular}{|c|c|c|c|c|}
\hline BENEFICIARY & $\begin{array}{l}\text { mid-July } \\
1944\end{array}$ & St Malo & Undetermined & Seize ports \\
\hline SWORDHILT & $\begin{array}{l}\text { late-July } \\
1944\end{array}$ & Brest & Undetermined & Seize ports \\
\hline TRANSFIGURE & $\begin{array}{l}17 \text { August } \\
1944\end{array}$ & $\begin{array}{l}\text { Paris- } \\
\text { Orleans gap }\end{array}$ & $\begin{array}{l}\text { 101st (US), 1st } \\
\text { (UK), Polish } \\
\text { BDE } \\
\end{array}$ & $\begin{array}{l}\text { Trap 7th Army (German) } \\
\text { (cancelled because ground } \\
\text { forces overran objective) }\end{array}$ \\
\hline BOXER & $\begin{array}{l}\text { late- } \\
\text { August } \\
1944 \\
\end{array}$ & Boulogne & Undetermined & $\begin{array}{l}\text { Seize ports; harass retreating } \\
\text { German forces (cancelled } \\
\text { because of mission shift) }\end{array}$ \\
\hline LINNET & $\begin{array}{l}2 \\
\text { September } \\
1944 \\
\end{array}$ & Tournai & $\begin{array}{l}\text { 82nd (US), } \\
\text { 101st (US), 1st } \\
\text { (UK), Polish } \\
\text { BDE }\end{array}$ & $\begin{array}{l}\text { Cut off retreating German forces } \\
\text { (cancelled because of weather) }\end{array}$ \\
\hline LINNET II & $\begin{array}{l}4 \\
\text { September } \\
1944\end{array}$ & Liege & $\begin{array}{l}\text { 82nd (US), } \\
\text { 101st (US), 1st } \\
\text { (UK), Polish } \\
\text { BDE } \\
\end{array}$ & $\begin{array}{l}\text { Seize Meuse River crossing near } \\
\text { Aachen-Maastricht gap }\end{array}$ \\
\hline COMET & $\begin{array}{l}7 / 8 \\
\text { September } \\
1944\end{array}$ & Arnhem & $\begin{array}{l}\text { 1st (UK), Polish } \\
\text { BDE }\end{array}$ & $\begin{array}{l}\text { Seize bridges from Eindhoven to } \\
\text { Arnhem (on } 8 \text { Sep, cancelled } \\
\text { because of weather) }\end{array}$ \\
\hline INFATUATE & $\begin{array}{l}\text { September } \\
1944\end{array}$ & $\begin{array}{l}\text { Walcheren } \\
\text { Island }\end{array}$ & Undetermined & $\begin{array}{l}\text { Assist 1st Army (Canada) in } \\
\text { clearing Scheldt Estuary (not } \\
\text { conducted because of mission } \\
\text { profile) }\end{array}$ \\
\hline NAPLES I & $\begin{array}{l}\text { September } \\
1944\end{array}$ & Aachen & $\begin{array}{l}\text { 18th ABN } \\
\text { Corps (US) }\end{array}$ & $\begin{array}{l}\text { Assist 1st Army (US) to break } \\
\text { through Siegfried Line }\end{array}$ \\
\hline NAPLES II & $\begin{array}{l}\text { September } \\
1944\end{array}$ & Cologne & $\begin{array}{l}\text { 18th ABN } \\
\text { Corps (US) }\end{array}$ & Seize Rhine River bridges \\
\hline MILAN I & $\begin{array}{l}\text { September } \\
1944\end{array}$ & Trier & $\begin{array}{l}\text { 18th ABN } \\
\text { Corps (US) }\end{array}$ & $\begin{array}{l}\text { Assist 3rd Army (US) in } \\
\text { penetrating Siefried Line } \\
\text { (cancelled because tactical } \\
\text { situation did not support } \\
\text { operation) }\end{array}$ \\
\hline MILAN II & $\begin{array}{l}\text { September } \\
1944\end{array}$ & Coblenz & $\begin{array}{l}\text { 18th ABN } \\
\text { Corps (US) }\end{array}$ & $\begin{array}{l}\text { Assist in Rhine Crossing } \\
\text { (cancelled because tactical } \\
\text { situation did not support } \\
\text { operation) }\end{array}$ \\
\hline CHOKER I & $\begin{array}{l}\text { September } \\
1944\end{array}$ & Saarbrucken & $\begin{array}{l}\text { 18th ABN } \\
\text { Corps (US) }\end{array}$ & $\begin{array}{l}\text { Assist 7th Army (US) to break } \\
\text { through Siegfried Line }\end{array}$ \\
\hline CHOKER II & $\begin{array}{l}\text { September } \\
1944\end{array}$ & Mannheim & $\begin{array}{l}\text { 18th ABN } \\
\text { Corps (US) }\end{array}$ & Assist in Rhine Crossing \\
\hline TALISMAN/ECLIPSE & $\begin{array}{l}\text { September } \\
1944\end{array}$ & Berlin & Undetermined & $\begin{array}{l}\text { In event of sudden German } \\
\text { collapse, seize airfields }\end{array}$ \\
\hline
\end{tabular}

Figure 4. SHAEF Airborne Operations Planned but Not Conducted, June-September 1944 
Eisenhower reserved decisions to employ the FAAA for himself. Both of his Army Group commanders wanted access to this force - Montgomery for an airborne operation to back his "single thrust" to Berlin strategy and Bradley for the aircraft to bring supplies forward. In early September 1944, both commanders had plans which included shutting down major German industrial areas. ${ }^{5}$

On 23 August 1944, Eisenhower gave Montgomery priority for use of the FAAA. Within a few days, Montgomery proposed Operation COMET, a vertical, double envelopment, where one airborne division plus an airborne brigade would be employed to secure bridges over waterways from the Belgian-Dutch border up to the Lower Rhine River near Arnhem, Netherlands. ${ }^{6}$ After moving through the airborne force and with the last water obstacle cleared, the route into the Ruhr industrial heartland in Germany would be open to the Allied ground force. With airborne troops loaded on aircraft, COMET was cancelled on 8 September 1944 because of weather. Despite this setback, Montgomery remained committed to the overall plan. To address issues raised during COMET planning, Montgomery increased the size of the airborne force to three divisions plus one brigade. Luckily for Montgomery, Eisenhower believed it was time for a bold operation and approved the proposal: "Against a defeated and demoralized enemy almost any reasonable risk is justified and the success attained by the victor will ordinarily be measured in the boldness, almost foolhardiness, of his movements."” Eisenhower then resolved Montgomery's concerns about resupply and maintenance. Satisfied adequate resources were on hand, Montgomery set 17 September 1944 as the target date for the major operation, now code-named MARKET GARDEN. 
Bradley was amazed when he heard about the plan, "Had the pious teetotaling Montgomery wobbled into SHAEF with a hangover, I could not have been more astonished than I was by the daring adventure he proposed. . . . Monty's plan for Arnhem was one of the most imaginative of the war." But Bradley did not support it, “Just as soon as I learned of Monty's plan, I telephoned lke and objected strenuously to it. . . Ike silenced my objections; he thought the plan was a fair gamble. It might enable us to outflank the Siegfried Line, perhaps even snatch a Rhine River bridgehead."”

Montgomery briefed the plan to subordinate leaders on 10 September. It was the largest airborne operation in history. Considering the months allotted for planning the airborne phase of OVERLORD, one week of planning time was minimal. With the planning done for COMET as well as the other airborne operations not conducted in the previous three months, Montgomery and FAAA leaders viewed the planning time as adequate.

\section{Overview of Operation MARKET GARDEN ${ }^{10}$}

MARKET GARDEN was actually two operations. The airborne part - "MARKET" - included three divisions and a brigade from the FAAA. LTG Frederick A. M. "Boy" Browning, who was dual-hatted as the deputy commander of the FAAA and the commander of the $1^{\text {st }} \mathrm{ABN}$ Corps (UK), was selected as the airborne force commander. The $1^{\text {st }}$ ABN Division (DIV) (UK), commanded by Major General (MG) Robert "Roy" Urquhart, with the $1^{\text {st }}$ Parachute Brigade (Poland), commanded by MG Stanislaw Sosabowski, were the $1^{\text {st }} A B N$ Corps's contribution to the effort. MG Matthew B. Ridgway commanded the other major airborne organization in the FAAA - the $18^{\text {th }} A B N$ Corps (US). Although he played no direct part in the operation, Ridgway's $82^{\text {nd }}$ ABN DIV 
(US), commanded by BG James M. Gavin, and $101^{\text {st }}$ ABN DIV (US), commanded by MG Maxwell D. Taylor, would participate. The $9^{\text {th }}$ Troop Carrier Command (US), commanded by MG Paul L. Williams, the $38^{\text {th }}$ Group Transport Command ((Royal Air Force $(\mathrm{RAF}))(\mathrm{UK})$, commanded by Air Marshal Leslie N. Hollinghurst, and the $46^{\text {th }}$ Group Transport Command (RAF)(UK), commanded by Air Marshal Lawrence Darvall, were the Air Force units to provide lift support.

The MARKET mission was to "lay a 'carpet' of airborne forces across the five major water obstacles which existed on the general axis of the main road through Eindhoven to Uden, Grave, Nijmegan, and thence to Arnhem area."11

The ground force - "GARDEN" - was from the $2^{\text {nd }}$ Army (UK), commanded by General Miles Dempsey. With three corps abreast, the $8^{\text {th }}$ Corps (UK) moved to the east of the axis of advance, the $12^{\text {th }}$ Corps (UK) on the west, while LTG Brian Horrocks' $30^{\text {th }}$ Corps (UK) moved in the center as the main effort.

\section{$2^{\text {nd }}$ Army (UK) Organization}

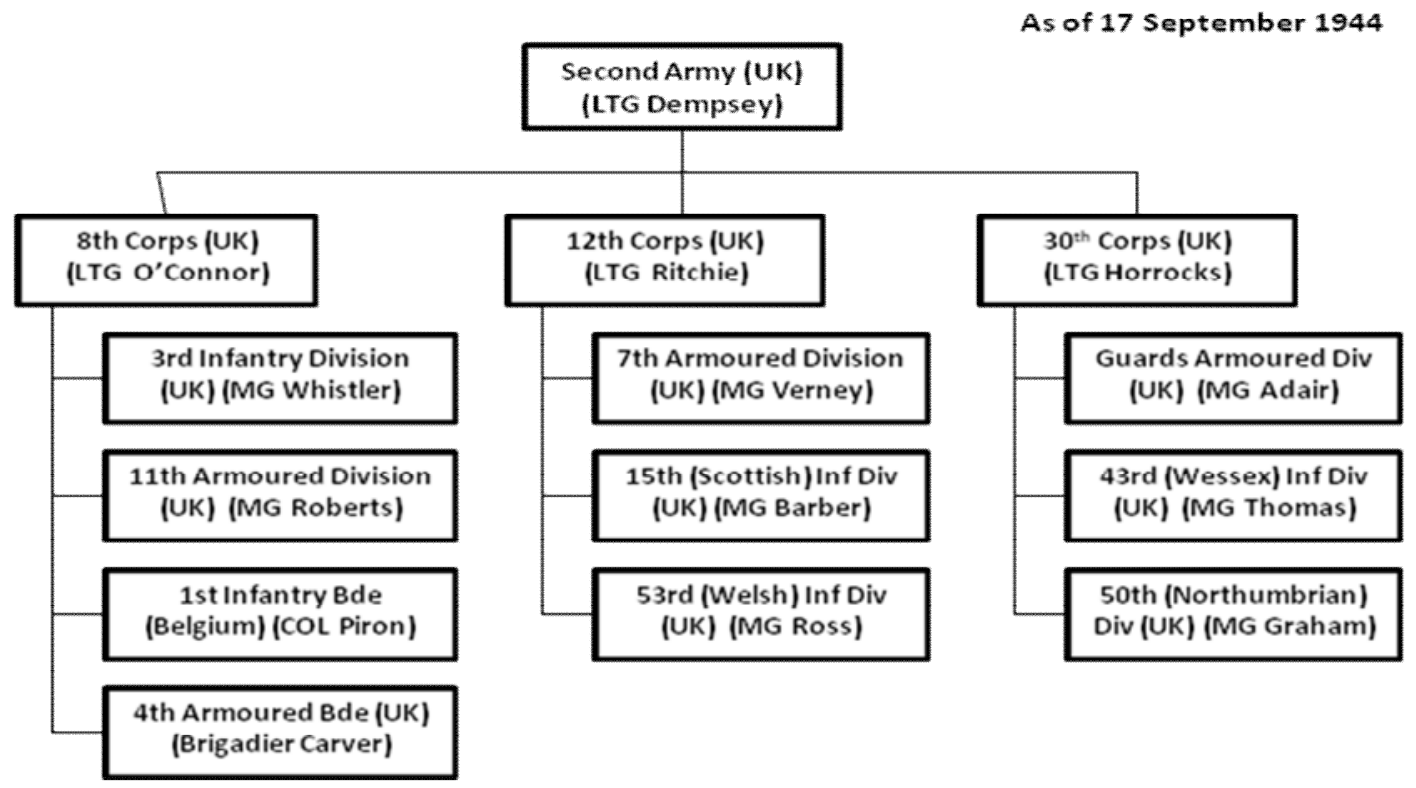

Figure 5. 
The plan called for lead elements of the ground force, led by the Guards Armoured Division and commanded by MG Allan Adair, to link up with the $101^{\text {st }} \mathrm{ABN}$ DIV vicinity Eindhoven by the end of D-Day (17 September), with the $82^{\text {nd }}$ ABN DIV vicinity Grave by the end of $D+1$ (18 September), and to reach the northernmost bridge and the $1^{\text {st }} A B N$ DIV by the end of $D+2$ (19 September). After passing through the airborne force, the ground force would move further east and encircle the Ruhr industrial heartland in Germany.

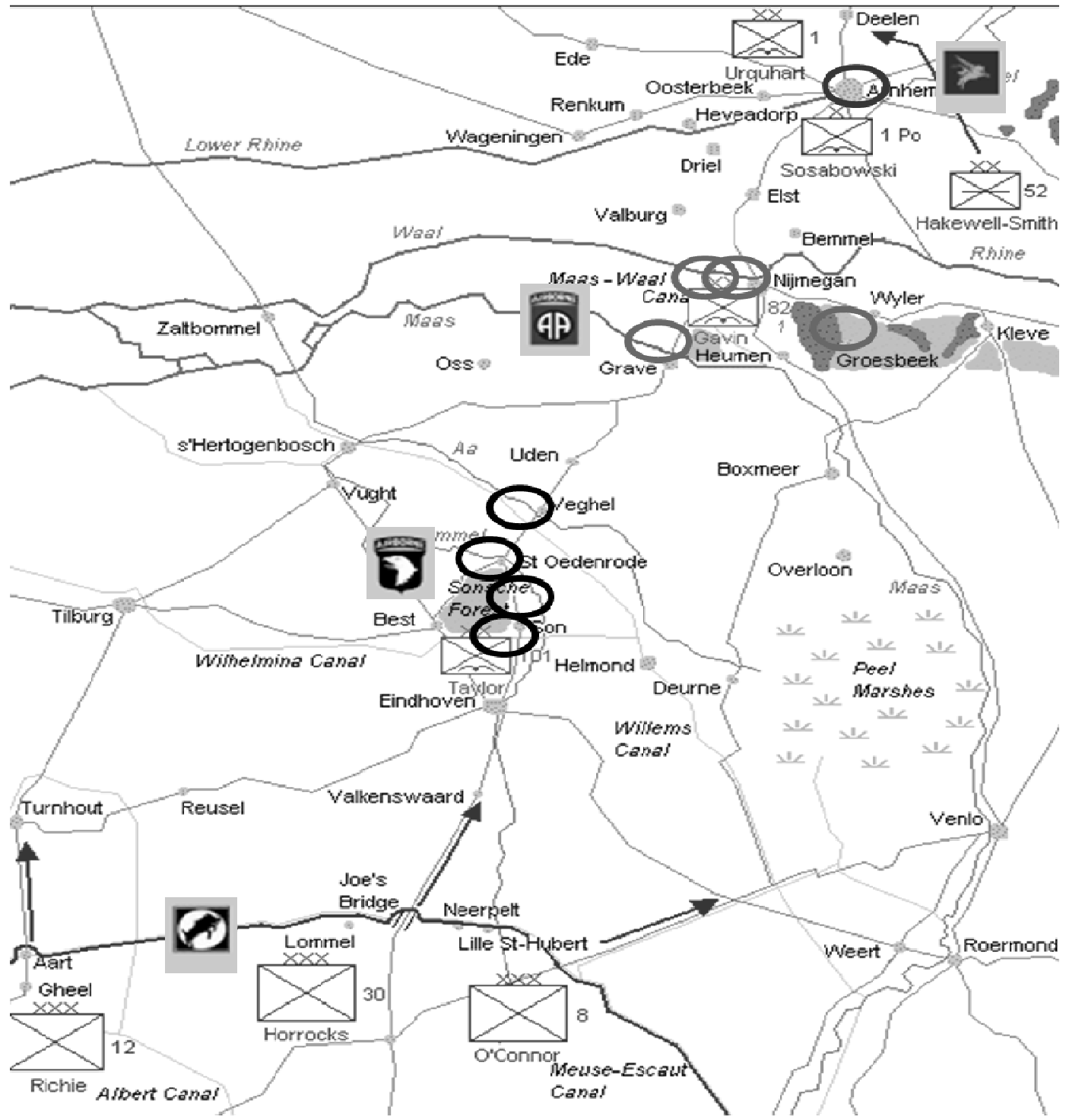

Figure 6. Operation MARKET GARDEN Plan ${ }^{12}$ 
Nineteenth century military strategist Carl von Clausewitz wrote this about river crossing operations:

A major river that cuts across the line of attack is a great inconvenience to the attacker. . . Worse, if he intends to offer a decisive battle on the far side, or if he expects the enemy to attack him, he will expose himself to grave danger. So no general will place himself in such a position unless he can count on substantial moral and material superiority. ${ }^{13}$

MARKET GARDEN relied on successfully crossing multiple water obstacles, adding significantly to the operations' complexity.

On Sunday afternoon, 17 September, D-Day, most of the ground force lined up on the south side of the Albert Canal near the Belgian-Dutch border. In an attempt to ensure security for the airborne force, Adair was instructed to keep border-crossing incursions to a minimum. His force launched after they saw aircraft flying in on the southern route, at approximately 1400 .

It was the first daylight airborne operation. Allied leaders were unsure how successful it could be, due to concerns over enemy defenses, most specifically flak. Intelligence reports estimated a high probability of flak throughout the area of operations, but especially from an area just north of Arnhem. Drop zones were selected with extreme caution favoring inbound aircraft. This hindered the placement of the $1^{\text {st }}$ ABN DIV; it had to use drop zones over eight miles from its primary objective - the bridge over the Lower Rhine River in Arnhem. It was the most successful airborne and glider action of the war. The loss rate of aircraft and crews was two and one half percent, far less than Normandy. Almost all paratroopers landed on or within a mile of their designated drop zones, far higher than Normandy. ${ }^{14}$

But the enemy situation the Allied forces found was different than they expected. After weeks of rapid advance, the Allies faced significant resistance. During the week 
halt for maintenance and resupply leading up to the battle, from 8-17 September 1944, German forces on the opposite side had time to reorganize, move into defendable positions, and prepare for renewed Allied attacks. Some of those German forces were armored units. The $2^{\text {nd }}$ Schutzstaffel (S.S.) Panzer Corps (German), including two Armored Divisions - the $9^{\text {th }}$ and $10^{\text {th }}$ S.S. - were moved to the Arnhem area to refit in early September.

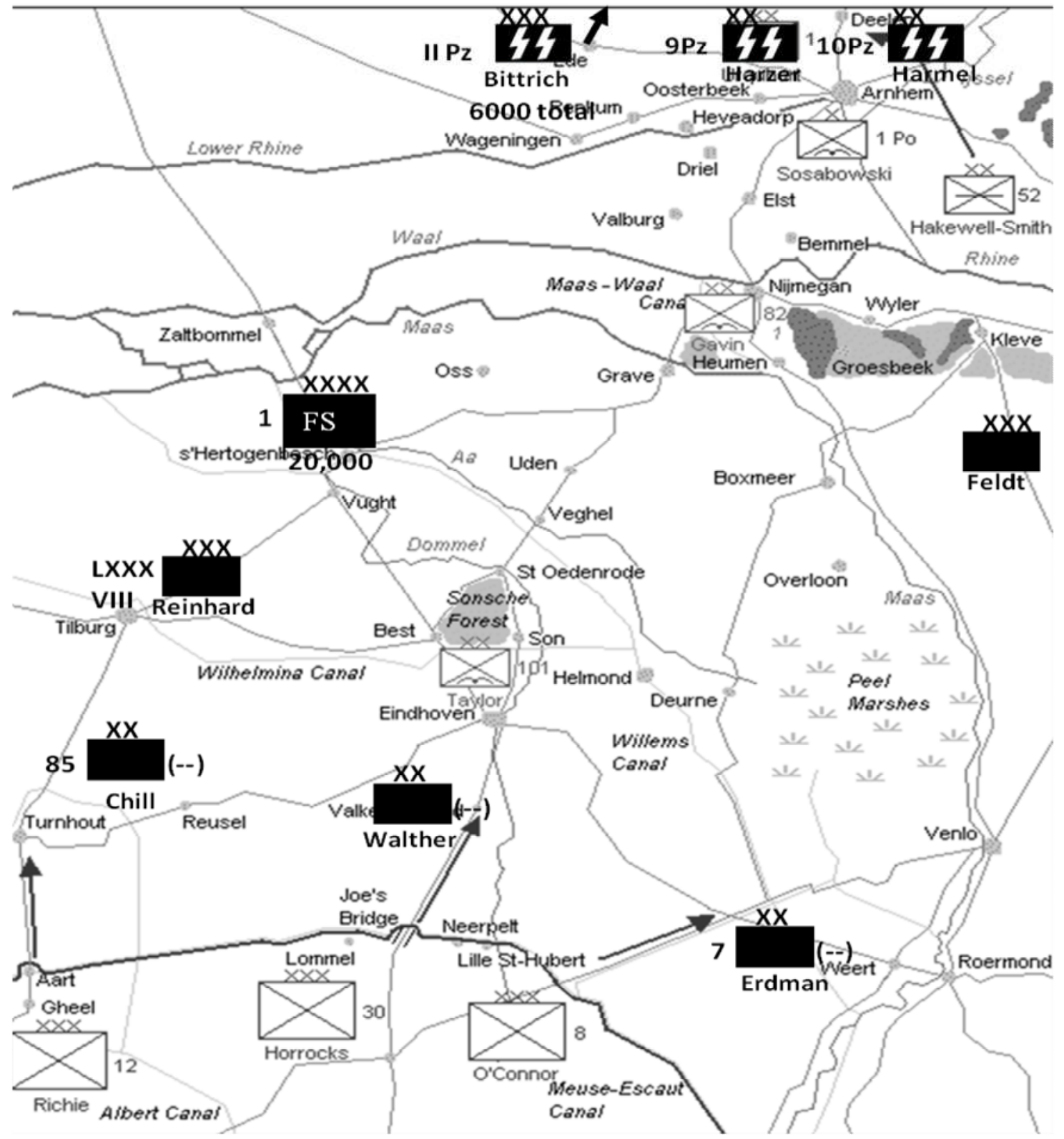

Figure 7. German Situation in Southeastern Netherlands-Early September $1944^{15}$ 
Airborne troops are not equipped to fight against large numbers of tanks and other armored vehicles. Additionally, the area of operations encompassed many natural obstacles, including rivers, canals, narrow ridges, and elevated roads on the edges of marshy fields. This, combined with the planned route for the ground force as one narrow, two-lane road, made the ground movement unbelievably difficult and laborious. The terrain and route in the area of operations left little possibility for maneuver, and German forces were able to significantly slow down the Allied ground force.

By the end of D-Day, the $101^{\text {st }}$ had secured all of its objectives except the bridge over the Wilhelmina Canal near Zon, which was blown up in the faces of the assault force. The $82^{\text {nd }}$ held the bridge over the Maas River near Grave, as well as one bridge over the Maas-Waal Canal and the critical high ground - the Groesbeek Heights. But they did not yet control either of the bridges over the Lower Waal River near Nijmegan. A small element of the $1^{\text {st }}$ controlled the northern end of the bridge over the Lower Rhine River at Arnhem. But the ground force had advanced only six miles, many miles away from the D-Day planned link-up site in Eindhoven with the $101^{\text {st }}$; they were already behind schedule.

German counterattacks along the route, especially along the road north of Eindhoven ( $101^{\text {st's }}$ area), the Reichswald Forest southeast of Nijmegan (82 ${ }^{\text {nd's }}$ area), and all around the bridge at Arnhem ( $1^{\text {st's }}$ area), kept significant pressure on the airborne forces. The other fifty percent of the airborne force was to be brought in over the next two days. However, bad weather in England and the Netherlands delayed this help. It took seven more days until the additional planned forces from the $1^{\text {st }}, 82^{\text {nd }}$, and $101^{\text {st }}$ ABN DIVs and the Polish ABN BDE arrived. Meanwhile, up to one third of the 
force already on the ground was committed to securing drop zones for follow-on forces, leaving even fewer paratroopers to accomplish their tasks.

The blown bridge at Zon (101 ${ }^{\text {st }}$ s area), fierce fighting to capture the road and railroad bridges near Nijmegan ( $82^{\text {nd, }}$ s area), and enemy counterattacks all along the route compounded the ground force delay. By the morning of 21 September, $D+4$, the ground force was just north of the Lower Waal River near Nijmegan. It took two more days to fight across the next few miles, and be at a point to stage the final advance on Arnhem. By then, the small $1^{\text {st }}$ ABN DIV force which had held the northern end of the Lower Rhine River bridge was defeated.

On the morning of 25 September, D+8, Browning and Horrocks, in consultation with Montgomery, agreed it was no longer feasible to continue the operation. During the night of 25-26 September 1944, the remnants of the $1^{\text {st }}$ ABN DIV and the Polish ABN BDE were evacuated south across the Lower Rhine River. More than 8,000 members of those formations were casualties. Operation MARKET GARDEN was over. It failed to secure the final bridge, thus making the overall operation a failure. The goal of establishing a bridgehead over the Rhine was not accomplished.

\section{Field Marshal Montgomery and the Decision to Launch Operation MARKET GARDEN}

So what went wrong? In his memoirs, Montgomery wrote:

In my-prejudiced-view, if the operation had been properly backed from its inception, and given the aircraft, ground forces, and administrative resources necessary for the job-it would have succeeded in spite of my mistakes, or the adverse weather, or the presence of the $2^{\text {nd }}$ S.S. Panzer Corps in the Arnhem area. ${ }^{16}$

He outlined four key reasons for the failure of the operation. While he was the architect of the plan, he had concurrence from Eisenhower and received feedback from 
others. What did senior leaders in the chain of command, from SHAEF down to division level, do or say to try to raise and/or resolve the issues later identified by Montgomery as reasons for the failure? For discussion purposes, Montgomery's key points are broken down and countered with documentary evidence of attempts made to resolve issues before the operation began.

Montgomery's First After Action Point.

The operation was not regarded at Supreme Headquarters as the spearhead of a major Allied movement on the northern flank designed to isolate, and finally to occupy, the Ruhr-the one objective in the West which the Germans could not afford to lose. There is no doubt in my mind that Eisenhower always wanted to give priority to the northern thrust and to scale down the southern one. He ordered this to be done, and he thought it was being done. It was not being done. ... ${ }^{17}$

Actions and Comments by Other Senior Leaders. Eisenhower did not agree with this perspective. Eisenhower had given Montgomery access to the entire SHAEF strategic reserve, as well as priority on maintenance and supply. On 14 September 1944, he wrote Marshall, "I have sacrificed a lot to give Montgomery the strength he needs to reach the Rhine in the north and to threaten the Ruhr.."18 On 29 September 1944, three days after the operation ended in failure, Eisenhower wrote Montgomery, "When I visited you on the $10^{\text {th }}$ you felt that the strength you then had, when supplemented by some additional maintenance from the U.S. side, would be sufficient to take care of the job north...up into the Rhine."19

Analysis. Upon reflection, it is easy to disagree with Montgomery's perspective. He did not want simply a priority on maintenance and supply for MARKET GARDEN; he wanted it all, with the rest of the Allied force be put on hold. This was an unrealistic expectation. His perspective seemed to be biased for two different reasons. First, MARKET GARDEN was his big chance to prove Eisenhower wrong - his "single thrust" 
plan should replace "broad front" as the overarching strategy for SHAEF. Second, Montgomery could not get past fighting with US leaders Bradley and Patton. He perceived they received unfair quantities of supplies during this period when he was the priority, which was not the case in reality. As Bradley explained, "Montgomery accused me of having hedged on Ike's orders. . . . The charge was easily refuted, for it was Eisenhower himself who apportioned the tonnage allotments between them. We followed those requirements to the letter. . .."20

\section{Montgomery's Second After Action Point.}

The airborne forces at Arnhem were dropped too far away from the vital objective-the bridge. It was some hours before they reached it. I take the blame for this mistake. I should have ordered Second Army and 1 Airborne Corps to arrange that at least one complete Parachute Brigade was dropped quite close to the bridge, so that it could have been captured in a matter of minutes and its defence soundly organized with time to spare. I did not do so. ${ }^{21}$

Actions and Comments by Other Senior Leaders. The FAAA airborne leaders knew the eight miles from the $1^{\text {st }}$ ABN DIV's drop zones to its primary objective was impractical, but they were not able to overcome the issue with Brereton, MG Paul Williams, commander of the $9^{\text {th }}$ Troop Carrier Command, and the pilots of the FAAA. General Urquhart wrote about his concerns with the placement of the drop zone, "I should have liked to put in troops on both sides of the river and as close as possible to the main bridge. This was unacceptable to the RAF, however, because of the flak barrage. . .reported as extremely heavy in the Arnhem area."22 Ironically, the creation of the FAAA was based, in part, to ensure resolution of these issues. When Gavin heard Urquhart's plan and the distance from the drop zones to the bridge, he said to his G-3, Colonel John J. Norton, "My God, he can’t mean it."23 
But while Ridgway, Taylor, and Gavin had participated in airborne combat operations beginning with Sicily in July 1943, MARKET GARDEN was Urquhart's first airborne operation. His lack of experience may have played a role in how much he felt he could push back on the RAF. Sosabowski, whose Polish Brigade was to operate as part of the $1^{\text {st }}$, was skeptical from the initial commanders' briefing on 10 September. Gavin sat next to Sosabowski during the briefing and remembered what happened, "As the meeting seemed to be coming to an end, he sounded out quite loudly, 'But the Germans, how about the Germans, what about them?' I too was very much concerned about the Germans and the British $1^{\text {st }}$ Airborne Plan."24

While the airborne division leaders lamented this situation, Browning, as the overall airborne leader, could not disagree with the plan; his destiny was at risk. Browning led British airborne force development, but he had never led in combat. He disagreed with Brereton about planning factors for Operation LINNET II, which was to take place in early September 1944 but was cancelled. Browning was so frustrated, he submitted his resignation. Brereton informed Ridgway that in light of Browning's pending resignation, Ridgway would take command of airborne forces in the operation. While the disagreement between Brereton and Browning was resolved a few days later, the threat of Ridgway taking command of airborne forces in MARKET hung over Browning's head. ${ }^{25}$

In addition to the placement of the $1^{\text {st }}$ ABN DIV's drop zones, another disagreement between airborne leaders and pilots concerned support to the initial airborne drop. Based on available aircraft, only fifty percent of the planned airborne force was delivered on D-Day. Airborne leaders asked the pilots to make two round trips 
on 17 September 1944. Since initial element of surprise would be gone therefore increasing the risk, as well as concerns over aircraft wear and crew fatigue, Brereton and Williams chose not to support this request. Providing two lifts in one day was not unprecedented. Only one month before, the $9^{\text {th }}$ Troop Carrier Command provided two lifts on the first day of Operation DRAGOON with great success. ${ }^{26}$ The ability to have two lifts on D-Day was even more significant in light of Montgomery's next after action point - weather.

Even when considering the operation's failure and airborne casualties, in its after action report, the $9^{\text {th }}$ Troop Carrier Command included this as one of its conclusions:

Units should not be committed to more than one full lift per day. Had troop carrier forces been committed as was originally intended, i.e., to make a quick turn around to provide two complete lifts per day, results would have mounted into disorderly confusion. Insufficient time on the ground would have allowed no time for spot maintenance, quick repair of battle damage, and little or no time for crew rest. ${ }^{27}$

Analysis. Montgomery's after action comment on this point is valid. Multiple senior leaders did not do everything in their power to ensure the maximum number of paratroopers were at the right place on the ground on D-Day in the $1^{\text {st }}$ ABN DIV's area, as well as in the other two divisional areas. Because of Browning's tenuous position, Brereton and Urquhart's lack of airborne experience, and the inflexibility of the Troop Carrier units to fully support the operation, fifty percent of the airborne force never made it to the fight or made it too late to have an impact. Montgomery and Brereton should have directed these changes - both for the change in the placement of the $1^{\text {st }} s$ drop zones as well as the double mission on 17 September. Brereton later denied any FAAA actions contributed to the overall failure, "I oppose, however, any suggestion that the airborne operation in Holland was a failure. It was an outstanding success. We 
accomplished every mission assigned to us in the original plan.. ${ }^{28}$ While his airborne divisions fought as hard and held out as long as they were capable of doing, their degraded strength was due to his decisions on lift support.

Montgomery's Third After Action Point.

The weather. This turned against us after the first day and we could not carry out much of the later airborne programme. But weather is always an uncertain factor, in war and in peace. This uncertainty we all accepted. It could only have been offset, and the operation made a certainty, by allotting additional resources to the project, so that it became an Allied and not merely a British project. ${ }^{29}$

Actions and Comments by Other Senior Leaders. While no senior leader wrote about weather as an objection prior to the battle, it should have been considered by all. As early as June 1944, SHAEF reports began warning that operations in Western Europe would be hindered by bad weather by the end of the summer, "By September 20, at the latest, we can count upon the beginning of winter weather. After that date air operations will be spasmodic. ... we should strive in every possible way to make maximum use of our air during the next 60 to 90 days. ${ }^{30}$ Since bad weather caused the cancellation of other airborne operations, including Operation COMET just the week before, the potential impact of weather was not a novel idea.

Analysis. While there was nothing any senior leader could have done to affect the weather, they could have done things differently to mitigate the impact of bad weather. A plan this complex which relied on nearly perfect weather in England and the Netherlands for one week when considering the known weather patterns was unrealistic. Brereton believed weather had significant impact on the operation's outcome in three ways, "First, it hindered resupply, and secondly, it delayed the arrival of reinforcements. The comparative lack of air support. . .was due partly to weather." ${ }^{31}$ It 
could have been mitigated by some of the same ways described in Montgomery's second after action point - through the change in the placement of the $1^{\text {st }} \mathrm{ABN}$ DIV's drop zones to be closer to the bridge, as well as the double mission on 17 September. If both of these changes had occurred, there would be less need for additional forces to arrive quickly, so then if weather stopped reinforcements from arriving, as did happen, it would not have had such a significant impact.

Montgomery's Fourth After Action Point.

The $2^{\text {nd }}$ S.S. Panzer Corps was refitting in the Arnhem area, having limped up there after its mauling in Normandy. We knew it was there. But we were wrong in supposing that it could not fight effectively; its battle state was far beyond our expectation. It was quickly brought into action against the $1^{\text {st }}$ Airborne Division. ${ }^{32}$

Actions and Comments by Other Senior Leaders. Montgomery was incorrect in his assessment of the German fighting strength and will. He was not alone. At this point, after the great Allied sweep from Normandy to the Dutch-Belgian border in the north and the German border in the south, a wave of euphoria swept through the ranks. Not everyone had this perspective. Winston Churchill was more cautious: "Many factors induced a belief in our military circles that the Nazis would soon collapse. But I was not convinced. .. . I accordingly warned them against basing their plans on an imminent German collapse.. ${ }^{33}$ Captain Brian Urquhart, an intelligence officer on the $1^{\text {st }}$ Airborne Corps (UK) staff, was also skeptical: "I was also worried about General Browning and my brother officers. There seemed to be a general assumption that the war was virtually over and that one last dashing stroke would finish it. The possibility of German opposition was scarcely worthy of discussion." ${ }^{34}$ MG Urquhart observed similar attitudes, especially among ground forces who had helped with the rapid advance: "They were 'victory happy."”35 Of course they were! The Guards Armoured Division 
alone moved 250 miles in the six days leading up to the capture of Brussels just a few days earlier. ${ }^{36}$

A SHAEF planning policy memorandum on the establishment of airheads included guidance, "Because of the inherent weakness of airborne or air landed troops versus armour, it is desirable that the airhead be located a maximum distance from any known panzer division. ${ }^{37}$ SHAEF and $21^{\text {st }}$ Army Group intelligence summaries leading up to the operation kick off specifically mentioned the 9 th and $10^{\text {th }} \mathrm{S}$ S.S. Panzer Divisions were reorganizing and refitting in the Arnhem area. But the $2^{\text {nd }}$ Army and FAAA did not include these reports in their intelligence summaries, so their subordinate commands were not informed about this significant development. MG Urquhart was very concerned about the lack of intelligence available for the Arnhem area: "The planning of the operation was not helped by the scanty intelligence about what was coming our way....my intelligence staff were scratching around for morsels of information. ${ }^{38} \mathrm{He}$ added, "Browning himself told me that we were not likely to encounter anything more than a German brigade group supported by a few tanks. . . . The soldiers. . . were said to be few and 'of low medical category." 39 Captain Urquhart attempted in vain to get senior leaders including Browning to recognize this threat, "General Browning. . .seemed little concerned and became quite annoyed when I insisted on the danger. . [He said I] should not worry unduly, that the reports were probably wrong. . . . This reaction confirmed my worst suspicions about the attitude of Browning. . . ."40 For the next few days, he used all available intelligence assets, including aerial reconnaissance, to confirm these reports. His seniors did not want to hear his updates, however, and for his efforts, Captain Urquhart was relieved on 15 September $1944 .{ }^{41}$ 
The same intelligence gap happened from the ground force perspective. Horrocks lamented, "Why did I receive no information about the German formations which were being rushed daily to our front? For me, this has always been the sixty-four thousand dollar question." ${ }^{42}$

On 15 September 1944, Eisenhower sent his chief of staff, LTG Walter Bedell Smith, to Montgomery's headquarters to ensure the intelligence reports were not ignored, to no avail and with significant consequences: "Having authorized him to proceed, Eisenhower did not feel he could now instruct him not to do so, even though the head of his intelligence staff predicted a defeat." ${ }^{43}$ Even Bradley was frustrated: "My opposition. . .was not confined to the British diversion of effort. I feared also that Monty in his eagerness to get around Model's flank might have underestimated German capabilities on the lower Rhine." ${ }^{44}$

Even without intelligence reports, the senior ground commander in the area knew the situation was changing. On 9 September 1944, LTG Miles Dempsey, commander of $2^{\text {nd }}$ Army (UK), wrote in his diary:

It is clear that the enemy is bringing up all the reinforcements he can get his hands on for the defense of the ALBERT Canal, and that he appreciates the importance of the area ARNHEM-NIJMEGAN. It looks as though he is going to do all he can to hold it. This being the case, any question of a rapid advance to the North-East seems unlikely. . . . Are we right to direct Second Army to ARNHEM? ${ }^{45}$

He did not mention whether he discussed this trepidation with anyone. In the rest of this volume of his diary, covering 6 June -15 September 1944, it was the only order he questioned.

Analysis. It is unforgivable for intelligence of this magnitude to be withheld from subordinate commanders. Based on available intelligence reports, it appears the key 
intelligence was taken out at $2^{\text {nd }}$ Army and FAAA levels, so the leaders at fault were Montgomery/Dempsey and Brereton/Browning. Without all available intelligence, subordinate commands could not plan and equip their forces properly. Having this intelligence may have added a greater sense of urgency among the ground forces. Based on the mentality of subordinate airborne commanders, having this information may not have caused them to refuse to participate. When Brereton asked Ridgway about concerns raised by Browning and Sosabowski for a different airborne operation in early September 1944, Ridgway replied, "The commanders of the $82^{\text {nd }}$ and $101^{\text {st }}$ Divisions would not protest the execution of any decisions handed down to them. . . .they would do as ordered and make a 100 percent job of it." ${ }^{\text {46 }}$ If Ridgway had objected to the plan, even if he was not designated as a combat commander, it is reasonable to expect he would have raised his concerns. This intelligence would certainly have generated comments and changes, affecting the prioritization airborne commanders gave to weapons systems and ammunition taken forward on the initial lift as well as follow-on missions.

Additional After Action Considerations. In addition to Montgomery's four key points, based on other senior leader and unit after action reports, three other points should be explored: terrain, combat leadership, and "political" pressure.

Terrain. The plan relied on the armored, ground force to travel on a single, elevated road above marshy fields or in urban terrain for more than sixty miles in enemy-held territory while crossing multiple water obstacles.

Actions and Comments by Other Senior Leaders. Horrocks and Adair, as the senior ground leaders, were both concerned about the terrain. For Horrocks, it was his 
first and most important concern: "The country was wooded and rather marshy which made any outflanking operation impossible. The only thing I could do was to blast my way down the main road on a comparatively narrow front. ${ }^{, 37}$ By the afternoon of 19 September, D+2, only 48 hours after the battle began, Horrocks already knew the terrain and route were the cause of his formation's delay. He told Gavin, “Jim, never try to fight an entire Corps off one road." ${ }^{.48}$

Adair wrote, "It was novel in the extreme. It was clear that the advance throughout had to be virtually on a one-tank front. . . .I too had underestimated the problems of advancing on such a narrow front and across such difficult ground." ${ }^{29} \mathrm{His}$ Operations Officer, Freddie Hennessy, explained the complexity of the plan "like threading seven needles with one piece of cotton, and we have only to miss one to be in trouble. ${ }^{50}$

The 101st's commander, Taylor, also thought terrain was the key to the operation's failure:

The critical fault had been in the concept of an army on a front measured by the width of one road. Even if the British ground commanders had driven northward with the ardor of a Patton, that single road would have presented most serious logistical difficulties to sustained operations. As it turned out, it was the slowness of the ground advance and the bad luck of the British Airborne Division in landing among unreported German armored units that were the immediate causes of the failure of Arnhem. ${ }^{51}$

Analysis. This terrain information was known to Allied forces, through firsthand experience, intelligence estimates, and Dutch underground reports, as well as Dutch military advisors assigned to most Allied commands. As with the weather discussion, there was nothing senior leaders could have done to affect the terrain. But they could have done things differently to mitigate the potential impact of it. If one vehicle was hit, it took significant effort to push it off the road before the attack could resume, since there 
was no room to maneuver around it. For a plan this complex to rely on one road was unrealistic, especially with the stated timelines on which the airborne forces were reliant. Terrain issues could have been mitigated by expanding the $30^{\text {th }}$ Corps' avenue of approach to include a second roadway, if not immediately after crossing the BelgianDutch border, at least vicinity Eindhoven. The $30^{\text {th }}$ Corps moved with one division on point, leading one long convoy. It could have split its force so the leading divisions maneuvered abreast. Even these changes would have had minimal impact overall, as the roads were still elevated with marshy low fields alongside. There was no maneuver room, negating any benefit an armored force might bring to bear.

After the speed of advance in the weeks leading up to MARKET GARDEN, however, ground force leaders lost sight of terrain being a concern. At the end of August and beginning of September, the lead ground unit - the Guards Armoured Division covered 250 miles in six days. Sixty miles in two days probably seemed like a fairly easy task. Adair reflected on this situation, "I had no premonitions on the possibility of failure for I too had underestimated the problems of advancing on such a narrow front and across such difficult ground. ${ }^{.52}$ Soon after the battle, Montgomery agreed he had underestimated the impact of the terrain. As Bradley remembered it, "Monty ruefully conceded that his 'easy' path had concealed a briar patch.".53

Combat Leadership. Most post-battle comments about leadership were those raised by American leaders about British commanders.

\section{Actions and Comments by Other Senior Leaders.}

From Ridgway's perspective, the leadership issues were two-fold. Before the operation, he expected he would be selected as the MARKET commander. The US 
provided two of three airborne divisions, he had combat leadership experience, and he thought he could do a better job than Browning. Ridgway wrote, "I well remember my bitter disappointment when General Brereton announced that he was giving command of this operation to General Browning. ${ }^{.54}$ Ridgway as the airborne commander may have made a difference. Perhaps he would have ensured the $1^{\text {st }}$ ABN DIV drop zone and the double lift on D-Day issues were changed to be more advantageous to the airborne force. His combat experience, as well as that of his $18^{\text {th }}$ ABN Corps staff significantly greater than their British counterparts in the $1^{\text {st }} A B N$ Corps - may have had an impact.

But Ridgway also had a negative perspective about the GARDEN force leadership. "I have always felt, and I still feel, that the sluggish actions of the ground armies in that campaign were inexcusable. A more vigorous command supervision from the top could have driven that armored force through. ${ }^{.55} \mathrm{He}$ personally observed a situation which formed this perspective. On 20 September, $D+3$, he was moving through the battlefield near Eindhoven. He was alone but for his jeep, driver, and two aides.

[W]e came up with the advance elements of British armor. There a junior officer stopped me and told me I could go no further because the road in front was swept with small arms fire. So we stopped a minute to watch how good our British comrades would take out this resistance. They had the muzzles of their tank guns pointing down the road toward where the enemy was supposed to be, but not a shot was being fired. It was a demonstration of caution. . . .I had seen it, and dealt with it many times before. . . . I couldn't order this tank commander to move on down the road. So, after waiting about forty minutes, and seeing no visible effort being made to outflank this resistance. . .we (Author's note: "we" means Ridgway and his aides) started walking down the ditch along the side of the road. We went a mile and a half, perhaps, with every sense alert, but not a shot was fired at us. ... We moved on until we found General Max Taylor at the CP of the $101^{\text {st }}$ Division. ${ }^{56}$

So Ridgway with his lone jeep was able to move along while the ground force did not. 
Ground force action on 20 and 21 September (D+3 and 4) near Nijmegan provides another example of unnecessary delays, at least as perceived by airborne leaders. There was tough fighting between the troops of the $504^{\text {th }}$ and $505^{\text {th }}$ Parachute Infantry Regiments of the $82^{\text {nd }}$ and the Guards Armored Division against German forces holding the city and both the road and railroad bridges near Nijmegan. The $504^{\text {th }}$, commanded by Colonel Rueben Tucker, captured the northern ends of both bridges after crossing the Lower Waal River in British collapsible boats. Both bridges were open to ground forces on the evening of the $20^{\text {th }}$, but they did not begin their push further north toward Arnhem until the next day. Gavin wrote about the scene on the morning of the $21^{\text {st: }}$

Tucker was livid. I had never seen him so angry. He had expected that when he seized his end of the bridge, the British armor would race on to Arnhem and link up with Urquhart. His first question to me was, "What in the hell are they doing? We have been in this position for over twelve hours, and all they seem to be doing is brewing tea. Why in hell don't they get to Arnhem?" I did not have an answer for him. ${ }^{57}$

Urquhart, whose division took the brunt of the casualties, was frustrated with his own countrymen, "I could not help wondering why 30th Corps had been so slow and unaware of the urgency when they had a commander with such a capacity for dynamic human relations." 58

Horrocks believed he had done all he could to emphasize the need for maximum speed. In his operations briefing, he said, "Speed absolutely vital, as we must reach the lightly equipped $1^{\text {st }}$ British Airborne Division if possible in forty-eight hours. [I emphasized this several times over.]"59 But on reflection after the battle, he wrote, "The main criticism has always been that 30th Corps was very slow. If this is so, it was my fault, because all of the troops were imbued with a sense of desperate urgency." ${ }^{\circ 0}$ 
Analysis. Ridgway and Gavin's perspectives demonstrate at least at some points, the ground force did not move as urgently as was possible. Even though Horrocks emphasized speed, it was not applied across the ground force consistently. The initial timeline - to link up with the $101^{\text {st }}$ ABN DIV vicinity Eindhoven by the end of D-Day (17 September), with the $82^{\text {nd }} A B N$ DIV vicinity Grave by the end of D+1 (18 September), and to reach the northernmost bridge and the $1^{\text {st }}$ ABN DIV by the end of D+2 (19 September) - was unrealistic under the circumstances. It was even more unrealistic with there were any delays in the ground force movement not caused by terrain or heavy fighting. If those reasons are excluded, it does seem combat leadership among ground forces did play at least some role in the operation's failure.

"Political" Pressures. What role did pressure from others, whether senior or subordinate, military or political, play in the decision to launch the operation, even with the perspective of mounting concerns?

Actions and Comments by Other Senior Leaders. Since $21^{\text {st }}$ Army Group was in the fight, there was no pressure on Eisenhower or Montgomery related to the ground force. In fact, almost the opposite was true. By allowing $21^{\text {st }}$ Army Group to conduct MARKET GARDEN, Eisenhower permitted Montgomery to take efforts away from capturing the Scheldt Estuary to open the Antwerp port more quickly.

But Eisenhower did feel pressure to get the FAAA engaged. US Army Chief of Staff, GEN George C. Marshall, and his Air Force leader, GEN Henry “Hap” Arnold, wanted this expensive force to help pay for their investment. ${ }^{61}$ Throughout August and early September 1944, Eisenhower gave both Marshall and Arnold regular updates about attempts made to engage the airborne forces. ${ }^{62}$ 
Pressure also came from airborne force leaders; they wanted to get back into the fight desperately. Brereton wrote, "We were all glad to be getting into action. . . We have planned 18 different operations, some of which were scrubbed because our armies moved too fast and others because Troop Carriers were engaged in air supply." ${ }^{63}$ Urquhart was even more anxious, "By September 1944 my division was battle-hungry to a degree which only those who have commanded large forces of trained soldiers can fully comprehend. . . .We were ready for anything."64

Ground force commanders understood their counterparts' pressure. Horrocks wrote

It soon became obvious that the vast, highly-trained airborne army in the U.K. was bursting to go. Plan after plan was devised for their use, only to be discarded at the last moment as their objective had invariably been captured by our ground forces before they could get there. I almost began to apologize for the speed of our advance. ${ }^{65}$

Adair had a similar view: "During our advance from Normandy we had constantly been told that the airborne forces were about to be launched in one operation or another. This. . .airborne army was in the U.K., longing to go, almost at any price."66 Analysis. While the $82 \mathrm{nd}$ and $101^{\text {st }}$ did need time to reconstitute after Normandy, by late August 1944, two Corps worth of airborne forces sitting in reserve in England while the war raged on the Continent had to weigh heavily on Eisenhower's mind. He knew he had to get them into the fight. MARKET GARDEN provided the opportunity. It was the first planned airborne operations not cancelled because the Allied advance overran the drop zones or bad weather. All Eisenhower had to do was let the operation unfold as planned. He was almost the only leader who could have forced Montgomery to cancel it. Montgomery's own senior staff had significant concerns about the operation before it began, but they did not say anything, "They were conditioned not to challenge 
Montgomery's view of things. De Guingand (Author's note: Montgomery's chief of staff) might have done so, but he was away sick. General Dempsey did advise the field marshal to drop the operation, but to no avail." ${ }^{" 67}$

\section{$\underline{\text { Conclusions }}$}

Considering the seven factors used evaluate the battle, five of them could have been changed by senior leader decisions before the battle. Only two - weather and terrain - could not have been altered by senior leaders; however they could have amended the plan to minimize the effects of these two. Proper analysis would have highlighted how significantly the terrain could impact the armored ground force. That point alone should have forced senior leaders to question this dramatic plan.

When considering an airborne operation, Ridgway wrote

In any action, you must balance the inevitable cost in lives against the objectives you seek to attain. Unless, beyond any reasonable doubt, the results reasonably to be expected can justify the estimated loss of life the action involves, then for my part I want none of it. ${ }^{68}$

In retrospect, it seems that an objective review of the overall plan before 17 September 1944 would have shown reasonable doubt as to the results.

Clausewitz wrote, "Everything in war is very simple, but the simplest thing is difficult. . . . Countless minor incidents-the kind you can never really foresee-combine to lower the general level of performance, so that one always falls far short of the intended goal." ${ }^{69}$ For Operation MARKET GARDEN, this held true. Seemingly simple but poor decisions made by senior leaders compounded to cause the operation's failure with significant loss of life.

Ultimately, Eisenhower was responsible as the Supreme Allied Commander and the overall ground forces commander. Montgomery and Brereton worked directly for 
him. He gave Montgomery priority of use for the FAAA and approved the plan. He accepted the responsibility: "I not only approved Market-Garden, I insisted upon it. What we needed was a bridgehead over the Rhine. If that could be accomplished I was quite willing to wait on all other operations." 70

Most of the responsibility for the failure must fall on Montgomery. In addition to being the plan's architect, he repeatedly ignored key intelligence and information, including weather and terrain, which should have altered the overall plan, if not causing its cancellation. He disregarded warnings from senior advisors and commanders.

There is enough blame for others. From among FAAA leaders, Brereton and Browning both made critical errors. Brereton made numerous decisions which were overly cautious in their bias towards the airplanes and crews and against the airborne force. Browning's lack of combat experience and fear for his career and standing made him impotent in ensuring full and proper support for his airborne force. Among ground force leaders, while Horrocks emphasized the requirement for speed, his subordinates did not drive their hardest, even when problems caused by poor terrain are considered.

The Allied airborne force paid the price for the failure of Operation MARKET GARDEN. With an eighty percent casualty rate, the 1st ABN DIV (UK) was never reconstituted. The $82^{\text {nd }}$ and $101^{\text {st }}$ ABN DIVs (US) stayed on the line in the Netherlands until November 1944 and later participated, but in a ground role, during the Battle of the Bulge, December 1944-January 1945. Browning was transferred to the India-ChinaBurma Theater in November 1944. There was not another Allied airborne operation until March 1945 with Operation VARSITY, when the $17^{\text {th }}$ ABN DIV (US) assisted with Rhine 
River crossings in Germany. It was the last large scale - division and larger - airborne operation.

Many other airborne operations were planned and not conducted during the summer of 1944. With all of the concerns raised before the battle, why did MARKET GARDEN go forward? If a single factor is selected to define it, it would be politics - from two perspectives. Horrocks' thought it was because Eisenhower's large strategic reserve had to get in the fight: "General Brereton's powerful Allied Airborne Army in the U.K... . [T]he Arnhem operation had already been decided upon at the beginning of September, and the powers that be were not risking another cancellation at the last moment. ${ }^{71}$ Montgomery also had to prove his "single thrust" plan was better suited to bring World War II to a quick close than was Eisenhower's "broad front" strategy. Having been given Eisenhower's strategic reserve, he did not want to lose it to someone else's plan; it was the biggest advantage he might get. The many other airborne operations planned and not conducted in the summer of 1944 demonstrated he had to use them and quickly. Eisenhower's response: "What this action proved was that the idea of 'one full blooded thrust' to Berlin was silly."72 Eisenhower sacrificed an Allied division to allow Montgomery to prove it.

Operation MARKET GARDEN is one of the most studied and written about operations of World War II. It will continue to be so for several reasons: it was a valiant effort by a large airborne force behind enemy lines; it was an overall failure; in this one small part of the overall battleground between Allied and German forces and in one short period of time, there were more casualties from the airborne force alone than among all of the Allies on "D-Day"; and some of the most renowned leaders of twentieth 
century warfare played a role. For this battle, however, these leaders' poor decisions compounded with devastatingly horrific results.

\section{Endnotes}

${ }^{1}$ Headquarters First Allied Airborne Army, Operations in Holland September-November 1944 (England, n.p., 22 December 1944), 50; The D-Day Museum (Portsmouth, England) home page, http://www.ddaymuseum.co.uk/faq.htm\#whichtroop (accessed 2 May 2009); Clay Blair, Ridgway's Paratroopers: The American Airborne in World War II (Garden City, NY: Doubleday and Company, 1985), 349-350.

${ }^{2}$ Unless otherwise noted, this section was written as a compilation of multiple primary and secondary sources, including: Alfred D. Chandler and others, eds., The Papers of Dwight David Eisenhower, The War Years: IV (Baltimore, MD: Johns Hopkins University Press, 1970); Omar N. Bradley, A Soldier's Story (New York, NY: Modern Library, 1999); Field Marshal Bernard L. Montgomery, The Memoirs of Field Marshal Montgomery (New York, NY: DaCapo Press, 1982); Blair, Ridgway's Paratroopers; Chester Wilmot, The Struggle for Europe (Old Saybrook, CT: Konecky and Konecky, 1952); Charles MacDonald, The Siegfried Line Campaign, U.S. Army in World War II (Washington, DC: Center of Military History, 1963); and Martin Blumenson, Breakout and Pursuit, U.S. Army in World War II (Washington, DC: Center of Military History, 1961).

${ }^{3}$ Hugh M. Cole, "The Lorraine Campaign," linked from the Center of Military History Home Page at http://www.history.army.mil/books/wwii/lorraine/photos/maps/maplV.jpg (accessed 2 May 2009).

${ }^{4}$ Blair, Ridgway's Paratroopers, 295-296.

${ }^{5}$ Montgomery's 21st Army Group had its 1st Army (Canada) focused on continuing operations along the coast, including opening the shipping lanes into Antwerp. His $2^{\text {nd }}$ Army (UK) was the main effort, tasked to move northeast over the Rhine River, and then maneuver around the north side of the Ruhr industrial heartland. Operation MARKET GARDEN was to employ the FAAA to support the $2^{\text {nd }}$ Army's efforts, clearing a path over the Rhine River.

Bradley's proposal was for his $1^{\text {st }}$ Army (US), on his far left and tied on the far right of the $21^{\text {st }}$ Army Group, to move on the south side of the Ardennes Forest, then maneuver around the south side of the Ruhr, helping to encircle it. The $3^{\text {rd }}$ Army was poised to cross into Germany and quickly surround the Saar industrial area, second in importance to the Ruhr area.

For more information about the infighting between senior leaders, see GEN Dwight D. Eisenhower, Crusade in Europe (New York, NY: Doubleday, 1948), 304-310; and Montgomery, The Memoirs of Field Marshal Montgomery, 240-253.

${ }^{6}$ The main water obstacles were, from south to north, the Wilhelmina Canal, the Dommel River, the Willems Canal, the Aa River, the Maas-Waal Canal, the Maas River, the Lower Waal River, and the Lower Rhine (Neder Rijn) River. 
${ }^{7}$ Eisenhower, Crusade in Europe, 289-290.

${ }^{8}$ Bradley, A Soldier's Story, 416.

${ }^{9}$ lbid., 418.

${ }^{10}$ Unless otherwise noted, this section was written as a compilation of multiple primary and secondary sources, including: HQ FAAA, Operations in Holland September-November 1944; GEN Matthew B. Ridgway, Soldier: The Memoirs of Matthew B. Ridgway (Westport, CT: Greenwood Press, 1974); LTG James M. Gavin, On to Berlin: Battles of an Airborne Commander, 1943-1945 (New York, NY: Bantam Books, 1979); Major General R. E. Urquhart, Arnhem: The Greatest Airborne Assault of World War II-The Battle for the Lower Rhine, September 1944, (New York, NY: W.W. Norton, 1958); GEN Maxwell D. Taylor, Swords and Plowshares (New York, NY: DaCapo Press, 1972); LTG Lewis H. Brereton, The Brereton Diaries: The War in the Air in the Pacific, Middle East, and Europe (New York, NY: DaCapo Press, 1976); Chandler, The Papers of Dwight David Eisenhower, The War Years: IV; Bradley, A Soldier's Story; Montgomery, The Memoirs of Field Marshal Montgomery; Wilmot, The Struggle for Europe; MacDonald, The Siegfried Line Campaign; Blumenson, Breakout and Pursuit.

${ }^{11}$ Montgomery, The Memoirs of Field Marshal Montgomery, 258.

${ }^{12}$ COL James Scudieri, "Operation MARKET GARDEN," briefing slides, Carlisle Barracks, PA, U.S. Army War College, 27 April 2009.

${ }^{13}$ Carl von Clausewitz, On War (Princeton, NJ: Princeton University Press, 1989), 532.

${ }^{14}$ Headquarters, $9^{\text {th }}$ Troop Carrier Command, Operation Market: Air Invasion of Holland (n.p., 2 January 1945), i; Gavin, On to Berlin, 171-172.

${ }^{15}$ Scudieri, "Operation MARKET GARDEN," briefing slides.

${ }^{16}$ Montgomery, The Memoirs of Field Marshal Montgomery, 267.

17 Ibid., 265.

${ }^{18}$ Joseph P. Hobbs, Dear General: Eisenhower's Wartime Letters to Marshall (Baltimore, MD: Johns Hopkins University Press, 1999), 203.

${ }^{19}$ Chandler, The Papers of Dwight David Eisenhower, The War Years: IV, 2185.

${ }^{20}$ Bradley, A Soldier's Story, 405.

${ }^{21}$ Montgomery, The Memoirs of Field Marshal Montgomery, 266.

${ }^{22}$ Urquhart, Arnhem, 6.

${ }^{23}$ Gavin, On to Berlin, 165.

24 Ibid., 166. 
${ }^{25}$ Brereton, The Brereton Diaries, 337-338.

${ }^{26}$ Blair, Ridgway's Paratroopers, 344-345.

${ }^{27} \mathrm{HQ}, 9^{\text {th }}$ Troop Carrier Command, Operation Market: Air Invasion of Holland, 80.

${ }^{28}$ Brereton, The Brereton Diaries, 365.

${ }^{29}$ Montgomery, The Memoirs of Field Marshal Montgomery, 266.

${ }^{30}$ Headquarters, SHAEF, memorandum to the Chief of Staff, SHAEF (England: n.p., 23 June 1944), 1.

${ }^{31}$ Brereton, The Brereton Diaries, 364.

${ }^{32}$ Montgomery, The Memoirs of Field Marshal Montgomery, 266.

${ }^{33}$ Winston S. Churchill, The Second World War Volume VI: Triumph and Tragedy (Boston, MA: Houghton Mifflin, 1985), 131.

${ }^{34}$ Brian Urquhart, $A$ Life in Peace and War (New York, NY: W.W. Norton, 1991), 71.

${ }^{35}$ Headquarters, SHAEF, "Planning Staff," (England, n.p., 4 August 1944, 4; Urquhart, Arnhem, 203.

${ }^{36}$ MG Allan Adair with Oliver Lindsay, A Guard's General: The Memoirs of Major General Sir Allan Adair (London: Hamish Hamilton, $2^{\text {nd }}$ ed., 1977), 158.

${ }^{37}$ Urquhart, Arnhem, 203.

${ }^{38}$ Ibid., 7.

39 lbid., 9.

${ }^{40}$ Urquhart, A Life in Peace and War, 72-73.

${ }^{41}$ Headquarters, SHAEF, Office of Assistant Chief of Staff, G2, Weekly Intelligence Summary, (England, n.p., 16 September 1944); Headquarters, $9^{\text {th }}$ Troop Carrier Command, Annex No. 6 (Intelligence), "MARKET," (n.p., n.d.); First Allied Airborne Army, Operations "MARKET"-Operation Instruction No. 1 (n.p., n.d.); Urquhart, A Life in Peace and War, 70-76.

${ }^{42}$ LTG Sir Brian Horrocks with Eversley Belfield and MG H. Essame, Corps Commander (New York, NY: Charles Scribner's Sons, 1977), 83.

${ }^{43}$ Norman Gelb, Ike and Monty: Generals at War (New York, NY: William Morrow and Company, 1994), 362.

${ }^{44}$ Bradley, A Soldier's Story, 418.

${ }^{45}$ LTG Miles Dempsey, The First 100 Days: Operation Overlord - From The Beaches To The Dutch Frontier (diary written daily during course of war, 1944), 107. 
${ }^{46}$ Brereton, The Brereton Diaries), 339. As an example from a different operation, Ridgway disagreed with a planned operation for the $82^{\text {nd }}$ in Italy in 1943 , and was able to get it cancelled. Later he wrote, "And it seems to me, too, that the hard decisions are not the ones you make in the heat of battle. Far harder to make are those involved in speaking your mind about some hare-brained scheme which proposes to commit troops to action under conditions where failure is almost certain, and the only results will be the needless sacrifice of priceless lives." Ridgway, Soldier, 82-83.

${ }^{47}$ LTG Sir Brian Horrocks, A Full Life (London: Collins, 1960), 210.

${ }^{48}$ Gavin, On to Berlin, 188.

${ }^{49}$ Adair, A Guard's General, 163.

${ }^{50}$ Freddie Hennessy quoted in MG Allan Adair with Oliver Lindsay, A Guard's General: The Memoirs of Major General Sir Allan Adair (London: Hamish Hamilton, $2^{\text {nd }}$ ed., 1977), 163.

${ }^{51}$ Taylor, Swords and Plowshares, 96.

${ }^{52}$ Adair, A Guard's General, 163.

${ }^{53}$ Bradley, A Soldier's Story, 419.

${ }^{54}$ Ridgway, Soldier, 108.

${ }^{55}$ Ibid., 111.

${ }^{56}$ Ibid.

${ }^{57}$ Gavin, On to Berlin, 200.

${ }^{58}$ Urquhart, Arnhem, 185

${ }^{59}$ Horrocks, Corps Commander, 99.

${ }^{60}$ Ibid., 125.

${ }^{61}$ Russell F. Weigley, Eisenhower's Lieutenants: The Campaign of France and Germany, 1944-1945 (Bloomington, IN: Indiana University Press, 1990), 288-292.

${ }^{62}$ Chandler, The Papers of Dwight David Eisenhower, The War Years: IV, 2054-2145; Weigley, Eisenhower's Lieutenants, 288-292.

${ }^{63}$ Brereton, The Brereton Diaries, 343.

${ }^{64}$ Urquhart, Arnhem, 6.

${ }^{65}$ Horrocks, Corps Commander, 76.

${ }^{66}$ Adair, A Guard's General, 162. 
${ }^{67}$ Gelb, Ike and Monty, 362.

${ }^{68}$ Ridgway, Soldier, 83.

${ }^{69}$ Clausewitz, On War, 119.

${ }^{70}$ Chandler, The Papers of Dwight David Eisenhower, The War Years: IV, 2135.

${ }^{71}$ Horrocks, Corps Commander, 83.

${ }^{72}$ Chandler, The Papers of Dwight David Eisenhower, The War Years: IV, 2135. 
